\title{
A Tribute to Helmut KallmanN
}

\author{
BY ROBIN ELLIOTT
}

I first met Helmut Kallmann when I was a graduate student at the University of Toronto. When I decided to do a Canadian music topic for my doctoral thesis, my supervisor sent me to Ottawa to speak with the Chief of the Music Division of the National Library of Canada (as it was then). "If anyone else is working on this topic, Helmut will know about it," I was told. "If you get the green light from Helmut, that is all the approval I need for your thesis proposal."

Indeed, Helmut was a walking encyclopedia of music in Canada before the paper one came into existence. If the subject had anything to do with Canadian music, he either knew about it, or knew whom to ask to find out about it. Single-handedly at first during his 20 years at the CBC Toronto Music Library, and later with a wonderful team that he gathered about him at the Music Division, he ensured that the musical heritage of this country would be carefully preserved. Beyond amassing an incredible collection of musical Canadiana, he also ensured that it would be made known through the fine publications that he shepherded into being for the Music Division and the Canadian Musical Heritage Society, and through his unstinting work for two editions of the Encyclopedia of Music in Canada.

Everyone who cares about the musical life of Canada owes Helmut Kallmann an enormous debt of thanks for what he achieved in the course of his career. His work as a scholar and a librarian was born out of a passionate attachment to music as sound. My fondest recollection of Helmut is of reading through Mozart Violin Sonatas with him in Toronto when he came for a visit. His delight in our music making was sincere, genuine, even childlike in its innocent pleasure. It was one more thing to love about this modest, retiring, gentle man whose passion for sound brought to light the musical heritage of an entire nation.

ROBIN ELLIOTT is a professor of musicology and an Associate Dean at the Faculty of Music in the University of Toronto. He is actively involved in teaching at the undergraduate and graduate level and in the supervision of doctoral theses, in addition to his administrative work and research activities. He has published widely on various subjects within the field of Canadian music studies. 